\title{
Rolling Stones Do Gather: MS Istanbul Aya Sofya 3610 and Its Collection of Mineralogical Texts
}

\begin{abstract}
In the multiple-text manuscript (MTM) Istanbul Aya Sofya 3610, around a peculiar recension of the Pseudo-Aristotle On Stones, a constellation of texts dealing with stones, mineral and their use has gathered. This collection of texts represents an anthology of many different streams of tradition received in the early Abbasid time by the Arabo-Islamic cultural milieu, alongside with some of original compositions from the same period inspired by the reception of ancient and late-antique knowledge. The comparison with another MTM on stones, Paris BnF 2775, shows the formation of clusters of texts around a central one-that becomes the driving force of the collection-and their circulation as such. The focus on the layout and other codicological features of Aya Sofya 3610 reveals an interest for some of these technical materials in the late Mamluk time and hints at their possible inclusion in the Mamluk curriculum.
\end{abstract}

\section{The collection of texts}

The multiple-text manuscript (MTM) Istanbul Aya Sofya 3610 transmits the most inclusive version of the Pseudo-Aristotle (hereafter Ps. Aristotle) On Stones, along with a number of other technical texts about stones, minerals, and their manipulation. ${ }^{1}$

The elements of its textual architecture represent a summa of the different streams of tradition collected in the early Abbasid period (ninth to tenth century), deeply embedded in the multilingual atmosphere of the translation movement. These texts deal with minerals, stones, talismans, amulets, and mineral ingredients for medicine and alchemy.

Regardless of the fact that these texts were either composed anew in Arabic, or inspired by foreign texts-whose actual translation into Arabic remains ques-

1 For a general overview of the contents and its indirect tradition in Arabic, see Ullmann 1972a, 105-110; and Käs 2010, I 5-7. Recently, Fabian Käs has mentioned the Ps. Aristotle among the sources for al-Maqrīzì's essay on stones, in the hope of gaining more attention for MS Istanbul Aya Sofya 3610, see Käs 2015, 25-26. 
tionable-almost all of them are, indeed, presented as translations of nonArabic materials. This transfer of knowledge implies a refined cultural operation to recontextualise the text in the cultural milieu of reception, adapting it to the new readership.

\section{(a) Kitāb al-ğawāhir wa-l-aḥ̆ăr-'The book of gems and stones' (fols 1r-128v)}

At the end of the third book of the Meteorologica, Aristotle announced his intention to present, one by one, the minerals and stones whose genesis had just been explained in general terms. He never fulfilled this promise, but in the early Abbasid period a text was composed in Arabic-and then attributed to Aristotle-to fill this gap left by 'the Master of logic'. MS Istanbul Aya Sofya 3610 preserves the more inclusive version attested in the manuscript tradition, which counts several other witnesses. ${ }^{2}$ This is the first and more extended text in this MTM-the only one mentioned in the titlepiece as well-and, probably, the one that attracted the other materials on stones and minerals.

In the introduction, Ps. Aristotle's Book on stones is presented as a compilation of materials transmitted along a line that connects Hermes to Aristotle. The manuscript tradition, more generally, presents this text both as a translation and as an abridgement of the alleged Aristotelian original, produced by a mufassir (compiler), which is said to count seven hundred stones: ${ }^{3}$

2 See Ruska 1912. The text transmitted by MS Paris BnF Ar. 2772 represents the main stream of the tradition, which counts several other witnesses, see Ullmann 1972a, 105. Though quantity is not everything, the fact that MS Istanbul Aya Sofya 3610 counts 114 entries against the 72 of the Paris version edited by Ruska gives an idea of the degree of difference between the different recensions.

3 In the early Abbasid context, mufassir may be intended as 'translator'. In this meaning, for instance, the words appears in the incipit of the ninth-century Arabic translation of Euclid's Elements, a copy of which is preserved in a twelfth-century manuscript now in the Leiden collection, MS Leiden Or. 399. See Witkam 1978, 16-17; and Witkam 2007, No. 399. In this particular case, the mufassir appears to have conducted other operations as well, namely the selection of materials in order to abridge the alleged Aristotelian original. MS Paris BnF Ar. 2772 mentions the name of the book's alleged translator, Lūqā Son of Serapion (tarğamahū Lūqa aibn Isrāfiyūn), See Ruska 1912, 93 and 126; see also Ullmann 1971, 295. In MS Istanbul Sehid Ali Pasha 1840 (fol. 1v), a preliminary remark to the introduction reads: 'This book is an abridgement (muhtașar) in which we mention the useful properties of stones ascribed to Aristotle the Wise and philosopher, that Muhammad ibn 'Abd al-Malik composed/compiled (fassarahū) from the "Book of the Useful Properties of Stones" by Șumāḥus the Greek, and that [Muhammad] translated into Arabic'. 


\section{MS Istanbul Aya Sofya 3610, fols 1v-3r - Introduction}

I collected in this book of mine many writings on stones from a number of books, and everything that is described in the discourse of the 'Light of Science', Aristotle the Wise, who took from the book of Hermes the Wise.

It is said that the stones on earth are much more than what can be described or encompassed with a [single] science, and among them there are indeed noble and incisive sciences.

Among them, there are precious stones, stones that sharpen the mind, stones with a spirit and stones with a body, and I have described their substances, their properties, their colours, their varieties, their bodies, their mines, their formation, the manipulation of their colours, the effects of their influence.

And so, the one who reads in this book of mine must reflect on it with his rational mind; not making fun of it, but considering it as a treasure for future generations.

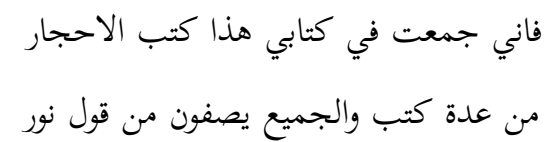

العلم ارسطاطاليس الحكيم المستخرج من

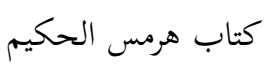

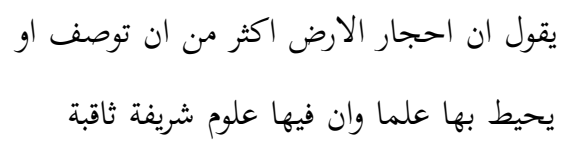

ومنها احجار نفسانية واحجار روحانية واحجار
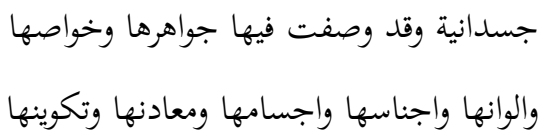

وتلوينها وتاثيراتها

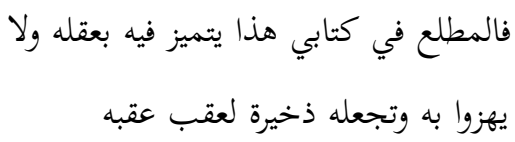

Each entry describes a stone or mineral and its varieties (usually identified on a chromatic basis), the places it is mined, followed by its medical and alchemical usage. Although the classification is not entirely consistent, the entries are arranged in larger groups (animal stones, magnets, etc.). The different components of the texts (varieties, mining places, medical and alchemical properties) were collected from different sources that can be tentatively identified: the Hermetic tradition, Sotakos (third-fourth century) for the geography of the mining places, the Lithognomon of Xenocrates of Ephesus for the animal stones, and the Physika of Democritus for the properties. ${ }^{4}$

4 See Ullmann 1972a, 96-101; Ullmann 1972b; Ullmann 1973; and van Bladel 2009, 121-132. 
The arrangement of the section devoted to metals and minerals follows the alchemical classification of these substances: (1) the seven metals that melt; (2) metals derived from those that melt; and (3) minerals in the form of powder. Below is an example from this last section, the entry for arsenic (zarnīh)

\section{MS Istanbul Aya Sofya 3610, fols 120r-121r}

\section{Property of arsenic}

Arsenic has many colours; there is the red, the yellow, and the dust-coloured one. If it is mixed with lime, it removes the hair and becomes a deadly poison.

As for the red variety, like the golden one, if one of the two is calcified until it whitens and melts copper, and then a bit of borax is added to it, this whitens it [copper], improves its appearance, and makes it easier to break into pieces. With its foul smell it chases [people] away. This is a mineral that has many mining places.

If it is burnt with fire and rubbed on the teeth, it will be useful to them, and avoid the [need for] drilling; even more arsenic enters in the [alchemical] art, and for those who paint on wood ${ }^{5}$ and in ointments.

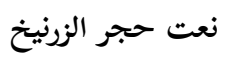

$$
\begin{aligned}
& \text { الزرنيخ الوان كثيرة فمنه الاحمر والاصفر والاغبر واذا } \\
& \text { جمع مع الكلس حلق الشعر وصار سما قاتلا } \\
& \text { فاما الاحمر كالذهبية ومن كلس احدهما حتى } \\
& \text { يبيض وسبك النحاس والقي عليه شىء من بورق } \\
& \text { بيضه وحسنه وحسن كسره واذهب برائحته المنتنة } \\
& \text { وهي حجارة لها معادن كثيرة } \\
& \text { واذا احرق بالنار ودلك به الاسنان نفعها واذهب } \\
& \text { بالحفر واكثر ما يدخل الزرنيخ في الصنعة وللداهنون } \\
& \text { في الخشب وفي المراهم }
\end{aligned}
$$

\section{(b) Na't al-sab'at ahğăarin_'Property of the seven stones' (fols 129r-137v) ${ }^{6}$}

Though this text is not a translation, it is definitely inspired by a Pahlawi lapidary, a fragment of which can also be found in the Turfan collection, in 'runic turc', and in a Sogdian manuscript of the Paris collection. ${ }^{7}$ The Pahlawi text presents a series of six coloured stones that -either independently, or as a result of the moist substance that they release when scraped-have a number of properties. The series of six stones is repeated six times, providing details of the

5 See Kazimirski 1860, I 745; and Lane 1863-1893, III 926-927.

6 The title given in the explicit (fol. 136v) is Kitāb ḩawāṣs al-sab'at ahğāāin .

7 See de Menasce 1942/1945; Ullmann 1972a, 102-104; and van Bladel 2009, $23-25$. 
properties of the differently coloured stones, and, only once per series, of the moist substance that they secrete.

In the Arabic recension of this text, the materials are enlarged and rearranged in a new textual structure, shared by all the manuscript witnesses to this text, notwithstanding its fluid tradition. ${ }^{8}$ The Arabic series counts one stone more-a dark blue one-and the innovation in the structural patterns is that the stones are dealt with one by one, and that their power is always conveyed by their moist secretion. That is to say, for each stone, the text details the properties of the six differently coloured secretions (all the colours except for the colour of the stone in question) produced by scraping it. ${ }^{9}$

In the Pahlawi tradition, the series of stones concludes with the stone that has seven colours. In the Arabic version, this last almighty rainbow stone introduces the following section, otherwise the stones would have become eight.

Below is a comparative table, in which the Pahlawi and the Arabic traditions, with their different structures, are displayed side by side.

8 Apart from the version of MS Istanbul Aya Sofya 3610, other manuscript witnesses to this text are MS Paris BnF Ar. 2775, fols 114r-116v and fols 96r-101r. For the non-casual order of the list of colours, the so-called Geiger's series, see Deutscher 2011, 25-77, in particular 44-45: 'On the basis of a few ancient texts and supported only by inspired inferences from some faint etymological traces, he thus reconstructs a complete chronological sequence for the emergence of sensitivity to different prismatic colours. Mankind's perception of colour, he says, increased "according to the schema of the colour spectrum": first came the sensitivity to red, then to yellow, then to green, and only finally to blue and violet. The most remarkable thing about it all, he adds, is that this development seems to have occurred in exactly the same order in different cultures all over the world. Thus, in Geiger's hands, Gladstone's discoveries about colour deficiencies in one ancient culture are transformed into a systematic scenario for the evolution of the colour sense in the whole human race. Geiger went further than Gladstone in one other crucial respect. [...] Gladstone has simply taken it as read that the colours on Homer's tongue matched exactly the distinctions his eye was able to perceive. [...] Geiger, on the other hand, realised that the relation between the perception of colour and its expression in language was an issue in need of addressing'.

9 The Arabic version could accommodate the new contents in the Pahlawi structure, by adding one stone to each series, and the respective colour liquids to each stone. The context of reception, however, opted for a different structure, or, alternatively, to had access to a different version of the Pahlawi text. My impression, however, is that similar rearrangements of textual blocks into new structures happened when the materials were transmitted across language boundaries. If one considers Geiger's argument of some value, the use of a different language may have opened new dimensions for the expression of the same core meaning. 


\begin{tabular}{|c|c|c|}
\hline & Pahlawi & Arabic \\
\hline Number of Stones & 6 & 7 \\
\hline Colours & $\begin{array}{l}\text { bright (transparent) } \\
\text { black } \\
\text { yellow } \\
\text { red } \\
\text { greenish } \\
\text { sky blue }\end{array}$ & $\begin{array}{l}\text { white } \\
\text { black } \\
\text { yellow } \\
\text { red } \\
\text { sky blue } \\
\text { indigo blue } \\
\text { green (leek) }\end{array}$ \\
\hline Order of the entries & $\begin{array}{l}\text { The series of six stones is repeated six } \\
\text { times, starting each time with a different } \\
\text { colour. }\end{array}$ & $\begin{array}{l}\text { Stones are dealt with one by } \\
\text { one, with the list of the effects } \\
\text { of the moist substance secret- } \\
\text { ed in six different colours } \\
\text { (always in the same order). }\end{array}$ \\
\hline Moist substance & $\begin{array}{l}\text { It is always white, occurs only once in } \\
\text { each series, always in the second posi- } \\
\text { tion, associated, in turn, with all the } \\
\text { different stones. }\end{array}$ & $\begin{array}{l}\text { It may take all the colours } \\
\text { except for the one of the stone } \\
\text { that releases it; its colours are } \\
\text { in the same order used for the } \\
\text { stones. }\end{array}$ \\
\hline
\end{tabular}

Here follows a sample from the text relating to the dark blue stone, added by the Arabic tradition, but nevertheless perfectly incorporated in the textual structure. Its peculiarity only emerges from a comparative perspective. 


\section{MS Istanbul Aya Sofya 3610, fols 134v-135v}

\section{Property of the blue stone, like the colour of indigo}

If you scrape it and the moist substance that comes from it when it is scraped is white, and if it is ground into the name of a woman, then she will love and follow [the man who does this].

And if women apply it as a salve onto the eyes of their husbands, then they will love them.

If the moist substance that comes out of it when it is scraped is black, then the people will honour [the one who uses it], and none of his orders will be disobeyed

And if the moist substance that comes out of it when it is scraped is yellow, then the one who wears it will become illustrious in all he does, and this will redouble any good thing that comes his way.

And if the moist substance that comes from it when it is scraped is red, anytime the one who has [the stone] turns it, then this will cause good luck, also financially.

If the moist substance that comes from it when it is scraped is the colour of the sky, then take it with you, since it is said that it will make [you] gentle.

And if the moist substance that comes from it when it is scraped is green, when the one holding it sits among the people, then they will honour him as long as the stone remains with him.

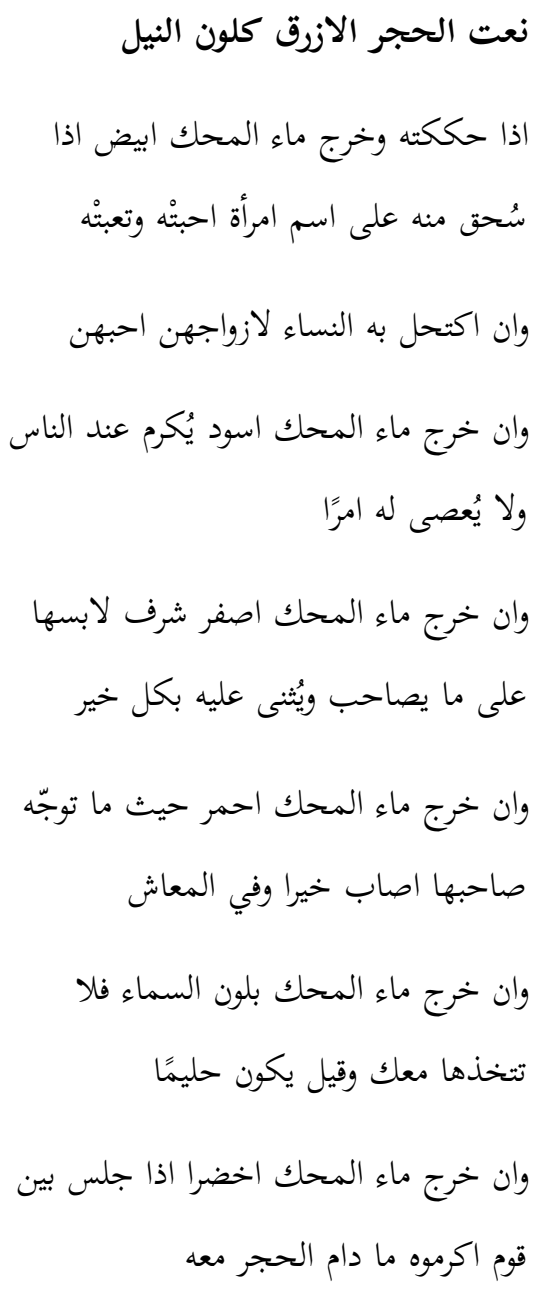


(c) Nat' al-ḩarazat al-mad'ūwa ğawharān šāh bi-l-lisān al-fārisīi ('property of the stone that is called ğawharān šāh in Persian', fols 136v-137v) - wa-hād̄a ḥağar ahar ('and another stone', fols 137v-138v) - na't ḥağar al-șunūnū ('property of the al-șunūnū bird stone', fols 138v-139r) - hağar al-'uqāb ('eagle stone', fol. 139r) - al-ḥağar alladī yaksiru al-zuğāğ ('stone that breaks glass', fol. 139v) - al-na't al-hağar al-zarzūrī ('property of the grey stone with white spots', fol. 139v).

The 'rainbow' stone, as anticipated, introduces a new text, and paves the way to other materials on animal stones and talismanic engravings. They are different from the animals with a stony nature mentioned in the Ps. Aristotle (the crab, for instance, or the sea urchin). Indeed, those mentioned here are stones found inside the body of particular animals, bezoars collected from animals other than goats.

Plausible sources for this kind of material is, again, the Lithognomon of Xenocrates of Ephesus, and the Physika of Democritus. ${ }^{10}$ Below is a section on the properties of the stone found inside a bird.

\section{MS Istanbul Aya Sofya 3610, fols 138v-139r}

Property of the șunūnū bird stone

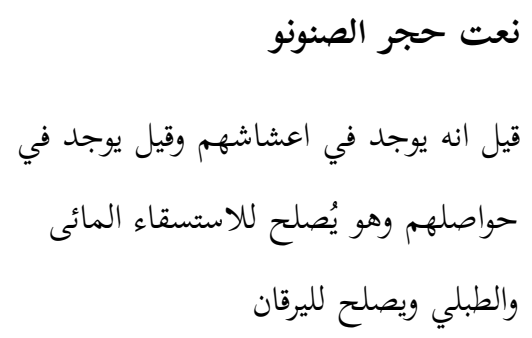

It is said that it can be found in their nests, and it is also said that it can be found in their craws, it is beneficial for watery and drumlike dropsy, and it is beneficial for jaundice.

10 See Ullmann 1972a, 98-99; Ullmann 1972b; and Ullmann 1973. 


\section{(d) Bāb fi asmä' haraz al-'Arab - 'Chapter about the names of the beads among the Arabs' (fols 139v-143v)}

Stones and minerals are perhaps one of the lesser productive fields of Arabic lexicography, when compared with records on other natural kingdoms. The characterization of the stones in lexicography is poetic, rather than technical. ${ }^{11}$ The lexicographers did not record names of stones, but rather adjectives and expressions to which they refer. The stones are grouped and described based on their shape, colour, dimension, hardness, etc. ${ }^{12}$ The intention to present all the talismanic lore connected to stones as an original Arabic product is clearly detectable in this short text. It gives voice, particularly to Arab women who claim they are capable of seducing their men by use of talismans and spells. The text is preceded by an introduction attributed to 'the philosopher', referring perhaps to the same Aristotle mentioned in the title page. ${ }^{13}$

\section{MS Istanbul Aya Sofya 3610, fols 139v-141r and fol. 142r}

The philosopher said: the sign of the opinion of the Ancients about the talismanic stones that we see, and the stones and the beads in our present time comes from the great number of engravings and figures that connect each stone to its variety, but they do not know what it is good for this, since they only appreciate its colours and its engraving.

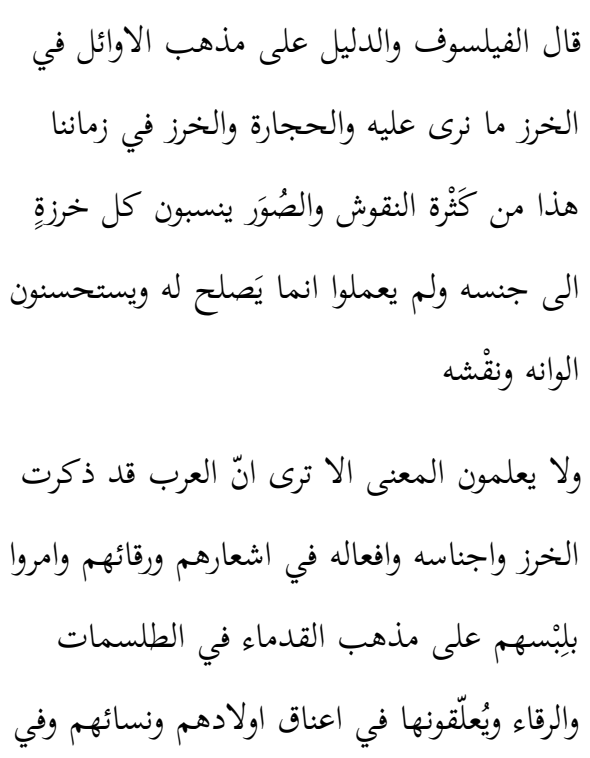

They do not know the meaning unless you consider that the Arabs had already mentioned the beads, their varieties, their effects in their poems, and their spells. They also prescribed wearing them, according to the opinion of the Ancients, as talismans and spells; they hung them round the necks of their children and of their women, on the necks of their horses, camels, sheep, and

11 The only poetical quotation (two verses) in MS Istanbul Aya Sofya 3610 is, in fact, on fol. 141 .

12 See Ullmann 1972a, 96-97.

13 'The philosopher' is not mentioned in another copy of the text transmitted in MS Paris BnF Ar. 2775, fols 99r-101r. 
other animals.

$$
\text { اعناق الخيل والابل والغنم وغيرها من الحيوان }
$$

Arab women maintain that they attract the desires of men by wearing the stones and

$$
\text { وتزعم نساء العرب انهم يجلبون اهوا الرجال }
$$

their spells. And the women use to say: 'we catch our men with our stones and our

$$
\text { بِلبْس الخرز ورقائها وقالت العامرية انا ناخذ }
$$

spells'.

$$
\text { رجالنا بخرزنا ورقائنا }
$$

As for the al-qila, this is a white gem that is usually hung on the neck of horses.

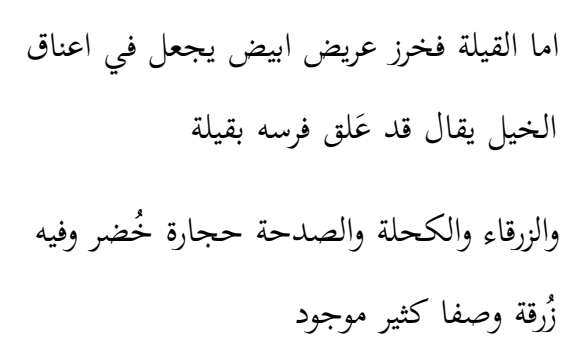

As for the al-zarqāa, ${ }^{14}$ al-kahla,${ }^{15}$ and $a l-$ sadha, ${ }^{16}$ these are green stones, with a bit of blue in them, and these stones are found in great number.

\section{(e) Kitāb 'Uțārid ibn Muḥammad'17 - 'Book of 'Uțārid ibn Muḥammad', on the seven stones of the planets and their engravings (fols 144v-164v)}

Attributed to Mercury (like the planet), son of Muhammad, is a composition that associates a stone to each of the seven planets, describing the appropriate astrological moment to engrave a talismanic image on it, the preparation of a signet ring to mount the stone, and the ritual prescriptions that must be followed by the one who wears it. ${ }^{18}$ The version preserved in MS Aya Sofya 3610, is not illustrated, an excep-

14 See Lane 1863-1893, III 1227: 'A certain bead for the purpose of fascination with which women fascinate men'; and Kazimirski 1860, I 986-987: ‘Coquillage qui certaines femmes arabes portent sur elles et auquel elles attribuent la vertu de faire aimer la personne qui la porte'.

15 See Kazimirski II, 2264: 'Sorte de coquillage qu'on porte comme un charme pour conjurer les effets du mauvais œil'.

16 See Lane 1863-1893, IV, 1227: 'A kind of bead used for the purpose of captivating or fascinating'; and Kazimirski 1860, II 1318: 'Espéce de coquillage employé comme amulette ou charme'.

17 The title is given in the explicit (fol. 168r). There it is also suggested that (e) and (f) were considered parts of the same work. Considering the new rubricated heading and the tradition of the series of engravings for planetary talismans, I have preferred to consider them as two separate texts.

18 See Raggetti 2014. 
tion in the manuscript tradition. The introduction repeatedly refers to ancient sources. In particular, it points out some Graeco-Egyptian sources, namely the Hermetic texts on stones and ancient Egyptian knowledge, and the Book of Talismans, regarding their useful properties, composed by the Seven Wise Men.

Some elements-ritual prescriptions, for instance, raffigurations and colours associated with the planets-suggest, however, a possible Indian origin for at least some components of the text. ${ }^{19}$ This work also used to circulate as one of the three chapters dealing with talismans in the Treasure of Alexander. ${ }^{20}$ The introduction, as in the case of the Ps. Aristotle, discusses several details connected to the translation of a technical text.

\section{MS Istanbul Aya Sofya 3610, fols 144v-145v - Introduction}

In the Name of God the Merciful the Compassionate, Praise to God Lord of the Worlds, the blessing of His Peace be upon our Lord Muhammad-Seal of the prophets-upon his Family and upon all his Companions.

The author of this book-may God, may He be exalted, have mercy of him-said: 'I have been searching the books of the ancient Egyptians (barābi) and in [the book] attributed to Hermes the Wise, in his volume (muṣhaf) known as Arḥānīqi (?), ${ }^{21}$ in which stones, plants, birds, animals, and snakes are mentioned.

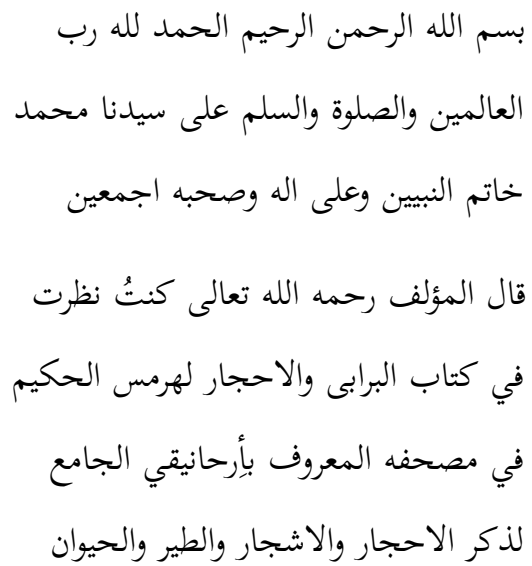

والحيتان

19 See Ruska 1919; and David Pingree 1989.

20 See Ruska 1926, 99; and Raggetti 2020 (forthcoming).

21 MS Paris BnF Ar. 2775, fol. 102v has the reading Awǧāyqu, that has been interpreted as physiologika, see Ruska 1919, 21. The interpretation, however, is a bit overstretched, and the reading of MS Istanbul Aya Sofya 3610, Arhāniqui, has the same chances of being the correct reading. This is a case of diffractio in which the judgement of the presence of the correct reading among the variants (or the lack thereof) is suspended, until the word behind the transliteration-possibly from Greek-is identified. The reading Awğāyqi, however, surfaces again in MS Paris BnF Ar. 2775, fol. 127r, in the incipit of a different text on planetary engravings. 
I have found their useful properties in the 'Book of Talismans' attributed to the Seven Wise Men, along with the use of stones, and the way to derive pleasure from them.

I found, however, that they were a problematic and obscure thing, like the things that are named by a kunya, since all the names of the stones and other as well were written in a foreign language (marsūm $^{u n}$ bi-l-lisān ala (̌ğamī).

So, I sought to polish all [these problematic aspects] away and make a revised and perfect book that can be used for this purpose. I did so, and the result is this very book that I have composed about the useful properties of stones and gems'.
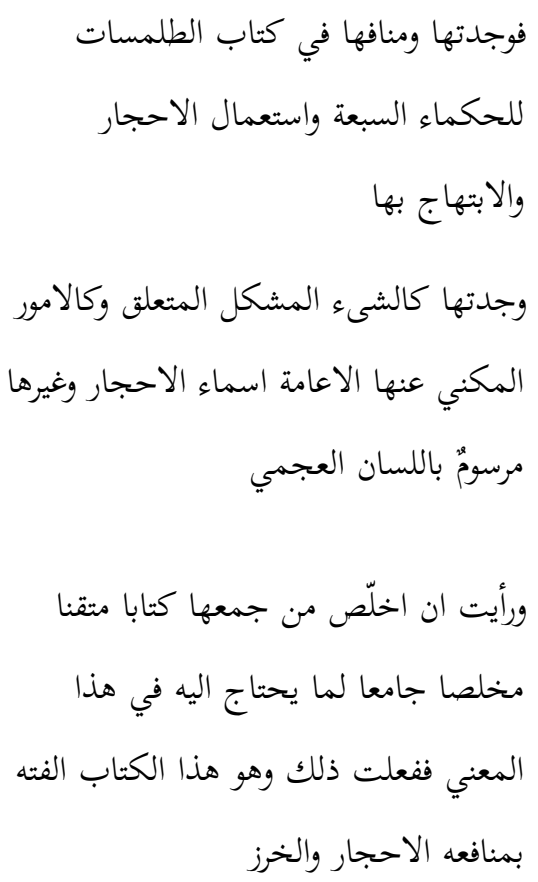

(f) Wa-hā $\underline{\text { dihi }}$ ğihāt al-ahğ $\bar{a} r$ wa-șifātuhā-'And this is the section of the stones and their peculiarities' (fols 164v-168r)-Sifat al-firūzăg ('description of the turquoise')-li-l-Muštarì haǧar al-mahā ('al-mahā stone, that pertains to Jupiter') ${ }^{22}$-li-l-Mirrīh hağar al-damm ('hematitis, that pertains to Mars'), li-l-Šams hağar al-mās ('diamond, that pertains to the Sun')]

This is a fragment from another Hermetic lapidary, which has a set of engravings that differs from 'Uțārid's series, but pays similar attention to the astrological components and the related ritual prescriptions. ${ }^{23}$

22 See Käs 2010, I 1059.

23 See Ruska 1919, 20-21. 


\section{MS Istanbul Aya Sofya 3610, fol. 165r}

\section{Property of the turquoise (fayrūzẵ)}

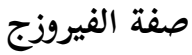

If it is engraved on a Wednesday with the figure of Mercury, when the Moon is in one of the two houses of Mercury-and the one who wears it should not eat donkey meat, or urinate in the dark-then he will magically subjugate the spirits dwelling in murky places, and they will show him where treasures are, with the permission of God, may He be exalted.

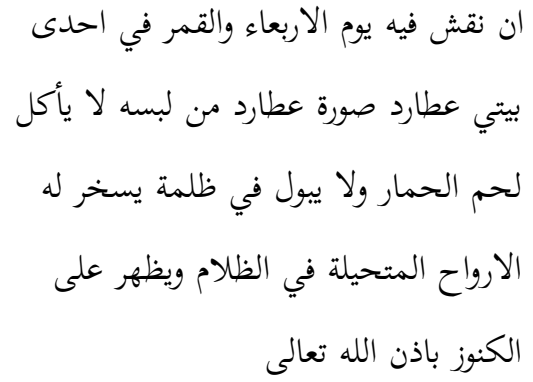

\subsection{Similar collections of texts in the composite MTM Paris BnF Ar. 2775}

The cluster of texts witnessed in manuscript Istanbul Aya Sofya 3610 is not unique, and can be compared to similar collections dealing with the different aspects of stone and mineral lore. Manuscript Paris BnF Ar. 2775 is a composite-and highly complex-MTM. It is composed of three recognizable circulation units bound together, and each of them includes more than one production unit. ${ }^{24}$ The definition of these three units can be made on the basis of some traces of quire numbering and of Western foliations. ${ }^{25}$ The first circulation unit

24 See Andrist / Canart / Maniaci 2013, 45-81.

25 The first circulation unit has the following quire numbering: fol. 15r tālit ('third'), fol. $24 \mathrm{r}$ rābi' ('fourth'), fol. 33r hāamis ('fifth'), fol. 43r sādis ('sixth'), fol. 53r sābi' ('seventh'), fol. 63r țāmin ('eighth'), fol. 73r tāsi' ('ninth'), fol. 81r 'äšir ('tenth'). The second circulation unit has no quire numbering; while the third has it: fol. 111r $\underline{t} \bar{a}[n \bar{\imath}]$ ('second'), [missing folia] fol. 115r taxalit ('third'), [fragmentary production units] fol. 131r rābi' ('fourth'), fol. 141r hā̄mis ('fifth'), fol. 151r sādis ('sixth'), fol. 161r sābi' ('seventh'). MS Paris BnF Ar. 2775 has different Western foliations: one for each circulation unit, and a fourth superimposed one that goes from the beginning to the end of the codex (which is used here to refer to the manuscript). This one was the last to be added. At the end of the second circulation units, on fol. 101r, there is an ownership note by Sulaymān al-Mutanabbī al-Ḥalabī, dated 976 H./1568-1569 CE. 
transmits a copy of al-Tīfāšì's work on stones and gems. The second one collects three fragmentary production units, all of them transmitting 'Uțārid's book on planetary engraved stones. The third contains an even higher number of production units and texts always dealing with astrological engraving of stones. In its complexity, manuscript Paris BnF Ar. 2775 provides us with multiple examples that can be compared with the contents of manuscript Istanbul Aya Sofya 3610.

Below is a detailed description of the contents of the Paris manuscript, in which the different production units are marked with an asterisk. The three circulation units are indicated by Greek letters. ${ }^{26}$ The great number of hands-definitely more than ten-and their non-peculiar features, however, do not allow for the cross-referencing of this information with the units of copy. When attested, next to each text of manuscript Paris BnF Ar. 2775, the corresponding text in manuscript Istanbul Aya Sofya 3610 is referred to using the lower case to which it is associated in the previous section.

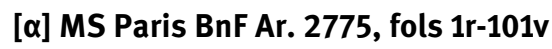

*(1r-75v) al-Tifāšì, Kitāb al-la'ālī al-muḍīy ya fì hawāṣṣ al-ğawāhir wa-l-ahğāâr almulūkiyya, 'The shiny pearls about the occult properties of gems and royal stones'.

\section{[ß] MS Paris BnF Ar. 2775, fols 102r-173v}

*(76r-89v) Kitāb hawāṣṣ al-ahğāar li-Hunayn bin Isḥāq (sic), 'Book of the occult properties of stones of Ḥunayn bin Isḥāq' $\rightarrow$ manuscript Aya Sofya 3610 (e) *(90r-95v) [Kitāb ḩawāṣṣ al-ahğḡar] acephalus ac mutilus $\rightarrow$ manuscript Aya Sofya 3610 (e)

- (96r-101r) - al-fïruzzağ $\rightarrow$ manuscript Aya Sofya 3610 (f)

- wa min manāfi al-ḥiğāra

- wa min țilasmāt al-hiğāra

- bāb fi maḥsanat al-aḥ̆ār wa-l-ḩaraz $\rightarrow$ manuscript Aya Sofya 3610 (b)

- asmā' haraz al- 'Arab (ownership note, 976 H. / 1568 CE) $\rightarrow$ manuscript Aya Sofya 3610 (d)

26 The three original production units probably circulated independently, and this MTM is the result of a later collection of fragments bound together, as their contents were perceived to be dealing with a common overarching theme. Only a partial history of this earlier stage can be reconstructed on the basis of the codicological clues offered by MS Paris BnF Arabe 2775. 
- $\quad$ [y] Manuscript Paris BnF Ar. 2775, fols 102r-173v

- *(102r-112v) Kitāb hawāṣs al-aḥğār li- 'Uțārid bin Muhammad, 'Book of the occult properties of stones of 'Uțārid bin Muhammad' $\rightarrow$ manuscript Aya Sofya 3610 (e)

- (112v-114r) Fìrūzăğ, Zuḥal, Muštarī $\rightarrow$ manuscript Aya Sofya 3610 (f)

- (114r-116v) Hādāa kitāb al-ahğār al-sabi'a wa-mā yanfa'u minhā fì ihtilāf alwāniha , 'This is the book of the seven stones and what advantage can be obtained from them on the basis of their different colours' $\rightarrow$ manuscript Aya Sofya 3610 (b)

- *(116v-121v) Șifat ahğār al-kawākib al-sabi'a wa-nuqūšihā 'alā țawāli', 'Description of the stones of the seven planets and their engravings on the basis of their ascendants' $\rightarrow$ manuscript Aya Sofya 3610 (e), with a different disposition of the materials: list of planetary stones followed by the description and the purpose of the engraving, Greek names for the planets $\rightarrow$ manuscript Aya Sofya 3610 (e)

- *(121v-122v) Hawāṣș al-aḥ̆ḡàr wa-l-nabāt, wa-tamma kitāb al-aḥ̆ḡa wa-lfușūs, 'Occult properties of stones and plants, the book on the stones and the gems is completed'.

- * (123r-123v) acephalus, explicit: Tamma kitāb al-ahğār wa-l-fuṣūṣ li- 'Uțārid bin Muhammad, 'The book of the stones and the gems attributed to 'Uțārid son of Muhammad is completed' $\rightarrow$ manuscript Aya Sofya 3610 (e)

- $\quad$ *(124r-126v) acephalus ac mutilus $\rightarrow$ manuscript Aya Sofya 3610 (e)

- (127r-131r) Kitāb Awğāyqi fi-l-țilasmāt, 'Book of the Awğāyqī (?) about talismans', Hermetic text on stones and talismans, peculiar set of engravings.

- (131v-161v) Risālat ba'd al-ḥukamä' wa-l-'ulamā' al-qudamā' fi-l-ğawāhir wa-l-ḩawāșs, 'Treatise of some ancient wise and learned men about gems and stones'

- (161v-173v) mutilus, Qāla Hirmis fi ğawāb al-aḥ̆ḡàr wa-ḩawāșșihā, 'Hermes in the answer about the stones and their occult properties said', Hermetic text on stones, talismans, planets and planetary magic.

A close comparison with manuscript Paris BnF Ar. 2775 reveals that the collection of texts transmitted by Aya Sofya 3610 probably represent a particular case of a more general trend, in which texts on stones and minerals, along with their properties and different technical applications, tended to cluster in particular ways and circulate together.

These clusters of shorter texts are sometimes attested in MTMs, in addition to more extended works on stones and mineral lore. As already observed for the 
Ps. Aristotle's Kitāb al-ahğār ('Book of Stones'), other texts could exercise a similar 'textual magnetism' and attract shorter texts. The second and the third circulation units of the composite MTM Paris BnF Ar. 2775 offer two different instances in which, in a context of fluid tradition, relatively short texts on stones and their manipulation clustered in similar ways, including in the unit 'Uțārid's book, other series of engraved planetary talismans, and the seven coloured stones. In addition to the contents, there is a codicological reason why these constellations of texts formed, i.e. none of them alone would have reached the critical mass of folia required for the composition of a codex. They circulated, therefore, in clusters that may happen to be attracted by and attached to a longer text dealing with the same or related topic. ${ }^{27}$

\section{The historical context of MTM Istanbul Aya Sofya 3610}

In the Mamluk period, it was quite common for copies not only to be made by professional scribes, but also by occasional copyists connected to the Sultan, or to the circles of the great amirs. ${ }^{28}$ Almost forty years ago, Barbara Flemming suggested that these lavishly decorated manuscripts, with their rich titlepieces represented 'special schoolexercises of the Mamluks', and that, at least in the last decades of the Burğì rule (13821517), Mamluk graduates (but also teachers) copied texts that were intended to enter the Sultan's library. ${ }^{29}$ More recently, Doris Behrens-Abousaif has taken up this idea and elaborated on it in her study of the book in Mamluk Egypt and Syria.

In the course of other research, I came across some manuscripts that show striking material similarities with manuscript Aya Sofya 3610. In the essays of Barbara Flemming and Helmut Ritter, I also found references to a consistent number of similar cases $^{30}$-which I mean to keep collecting. For this paper, however, there will be four comparanda for MS Aya Sofya 3610: MS Münster UB Or. 11, MS Istanbul Aya Sofya 2875, MS Leiden Or. 499 and MS Leiden Or. 303d..$^{31}$

27 My thanks to Marilena Maniaci, who suggested that I consider this codicological component in the clustering of texts and, more in general, in the genesis of an MTM.

28 See Flemming 1977, 249-260, and in particular 253.

29 See Flemming 1977, 258-259; and Behrens-Abouseif 2019, 96-102. The presence of scriptoria in the barracks seems to be attested in the sources only from the late fourteenth century.

30 See Behrens-Abouseif 2019, 96-102; Flemming 1977; and Ritter 1929, 116-154.

31 The selection of comparanda for this study is inevitably limited, for more than one reason. In spite of the lavish appearence of the title pages-that may lead us to think of them as absolutely 
The first and most visible of the common traits is the style of the titlepiece in the frontispiece, quite common between the thirteenth and fifteenth century in the Eastern part of the Arabo-Islamic world: one or more rectangular panels with a circular medallion ( ̌̌amsa) that either separates the panels, or is inscribed in one of them. The title is usually in the upper panel, while the medallion or the lower panel contain the ex-libris, introduced by the formula bi-rasm ('for', 'on the order of'). ${ }^{32}$ The ex-libris of the manuscripts analysed here define the chronological frame, by referring to two of the last Mamluk Sultans: Abū al-Nașr Sayf al-Dīn al-Ašrafī Qāytbāy (r. 1468-1496), and Al-Ašraf Qānșūh al-Ġawrī (r. 1501-1516).

The main case study and its comparanda will be described in succession, the transcription and English translation of the texts inscribed in the different titlepieces and colophons will be given as well.

1) The colophon of the MS Istanbul Aya Sofya 3610 tells us that its copy was completed in $888 \mathrm{H} / 1483 \mathrm{CE}$, placing the production of the manuscript in the late Burğ̄i Mamluk period. Though it includes a quite varied selection of texts, the title page of MS Aya Sofya 3610 only refers to the first and longest one, i.e. Ps. Aristotle's Kitāb al-ahğār. The text in the medallion (šamsa) tells that it was copied for the Sultan Qāytbāy by Muḥammad b. Aḥmad al-Farnawī al-mukattib ('teacher of the art of writing'). In the same year, al-Farnawī also copied Ibn al-Akfanī's Ġunyat al-labīb 'inda gaybat al-tabib ('The sufficient book for the intelligent person to use in the absence of a physician'), showing a non-purely occasional interest in technical literature. ${ }^{33}$

unique art objects, which, to us, they undoubtedly are-these manuscripts, which were probably produced in great number and somehow 'in series', are now scattered throughout numerous collections all over the world. It is also possible to find some interesting folia and titlepieces online, although many sources do not provide any reference to collections or any signature for the manuscripts. <www.digitaloccultmanuscripts.blogspot.nl>, for instance, has a copy of the Kitāb al-ğamāhir fi-l-ğawāhir ('The book of precious stones') by al-Bīrūnī, http://digitaloccult manuscripts.blogspot.nl/2009/12/ (last accessed, 24 September 2019), see Käs 2010, I 88-90; or the Kitāb al-tafhìm fi șinā'at al-tanğìm ('Book on the instruction about the art of astrology') of the same author http://digitaloccultmanuscripts.blogspot.com/2008/12/al-tafhim-li-awa-sina-al-tanjim. html (last accessed, 24 September 2019).

32 See Gacek 2009, 278-279.

33 See Flemming 1977, 253 (MS Istanbul Saray Ahmet III 2018); and Behrens-Abouseif 2019, 96. For the meaning of Mukattib, see Lane 1863-1893, VII 2591. Another interesting medical manuscript with similar features is a copy of the Kitāb mufarrih al-nafs ('Book of the soul-cheerer') kept in the 'Ārif Ḥikmat Library in Medina (MS Medina Maktaba 'Ārif Ḥikmat Țibb 20). It was the work of the copyist (al-nāsih) Ibrāhīm ibn 'Abd al-Raḥman al-Ṭarābulusī al-Ḥanafĩ for Muḥammad granson of the šayh al-Islām Burhān Allāh al-Yā'awī. My thanks to Robert Sieben- 
The frontispiece of MS Istanbul Aya Sofya 3610, is finely decorated by a titlepiece in blue and gold, with largely golden letters on a blue background featuring vegetal patters. However, in the medallion, the cloudbands have been filled with a criss-cross net of dark red. The page layout is composed of three main elements: the headpiece of a purely decorative rectangular band, the upper panel giving the title of the Ps.Aristotelian Book of Stones in a cartouche, and a squared and larger lower panel in which the medallion is inscribed. The medallion is scalloped and edged with eight semicircular projections. The band running along the middle and lower panels-also connecting them to the medallion-consists of a geometrical motif between two golden bands. The middle panel has a circular extension on the outer margin of the page, and the whole titlepiece has been outlined by a blue line (Fig. 1).

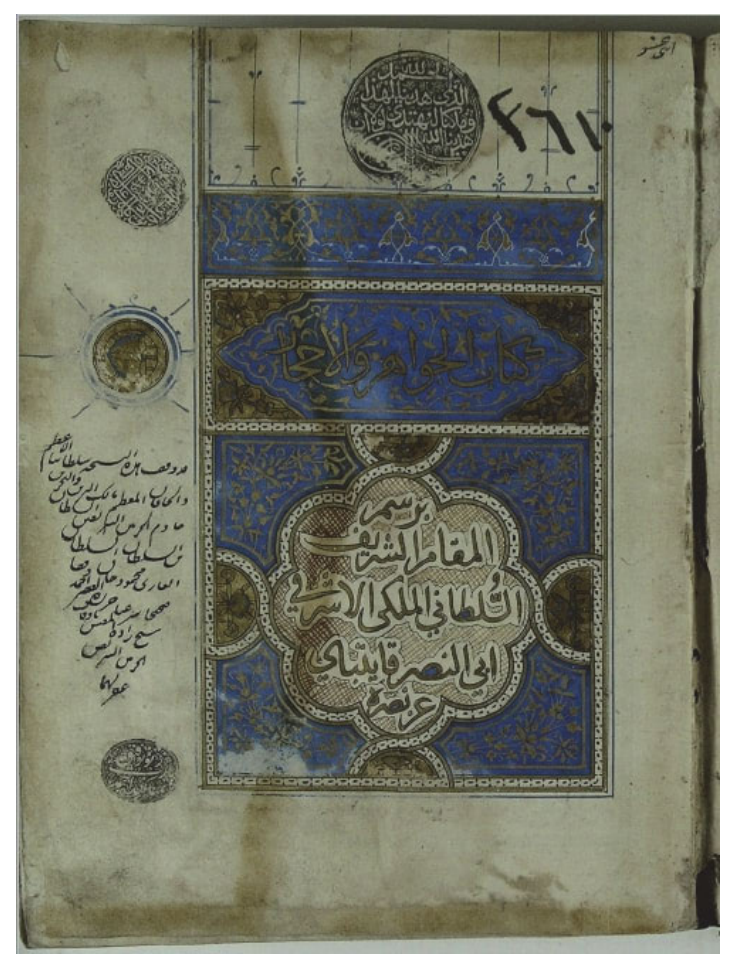

Fig. 1: MS Istanbul Aya Sofya 3610, fol. 1r. Titlepiece of the Ps. Aristotle’s Kitāb al-ahğār ('Book of Stones').

Tait-who is working on a critical edition of the Kitāb mufarrih al-nafs for his $\mathrm{PhD}-$ for bringing this manuscript to my attention. 
The title page shows a waqf certificate of the Sultan Mahmud I, together with its seal and that of his inspector for the waqf in Mecca and Medina. ${ }^{34}$ The chapter headings are written in red and in a larger script. The text dividers are emblazoned with stamped rosettes of blue, gold, ochre and yellow. Some appear to actually have the functional role of text dividers, others seem purely decorative. The text area is outlined by a treble-frame with two inner red lines and an external one of blue.

\section{Kitāb al-ğawāhir wa-l-ahğḡār, MS Istanbul Aya Sofya 3610, fol. 1r}

[Upper panel]

'The book of gems and stones'

[Lower panel / medallion]

For the noble rank of the Sultan al-Ašrafì Abū

Narṣ Qāytbāy may his victory be honoured.

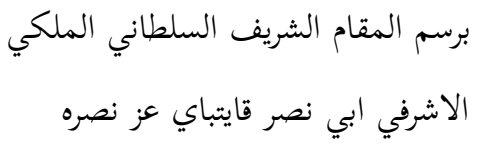

كتاب الجواهر والاحجار

MS Istanbul Aya Sofya 3610, fols

$168 r-168 v$

[Colophon]

The writing of this book was finished at the new moon of the month of Ša 'bān in the year 888 H./September 3, 1483 C.E., by the hand of Muḥammad b. Aḥmad al-Farnawī al-mukattib, may God have Mercy of him.

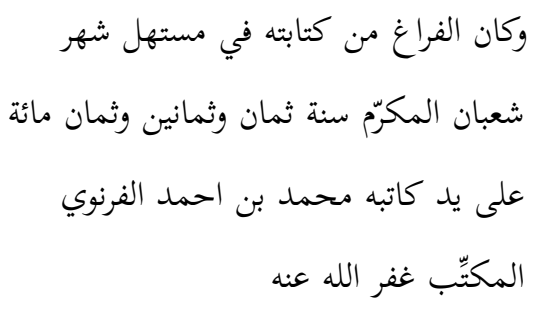

2) The first comparandum is the witness to a text on shooting with arrows, which definitely belongs to the furūsiyya ('the art of horsemanship') literature. It was copied for the Sultan Qāytbāy by the Mamlūk Yūsuf al-Muhammadī, who gives the name of his teacher (Muhammad al-Waqāy), and mentions the barracks to which he was affiliated (tabaqat al-Hawš). The titlepiece is composed of an upper and a lower panel with the title, while the medallion is included in the

34 For the seal of Ottoman Sultan Mahmud I (r. 1730-1754), see Hammer-Purgstall no. 1 and Chester Beatty Seals Database http://www.cbl.ie/islamicseals/View-Seals/124.aspx; while for the seal of Ahmed Şeihâde, the inspector of the waqfs in Mecca and Madina during the time of the Ottoman Sultan Mahmud I (r. 1730-1754) http://www.cbl.ie/islamicseals/View-Seals/125.aspx. 
square space between the panels. The medallion is outlined by a double-frame in red and blue, indented with golden drops. The background of the panels and that of the medallion is filled with undulating, pale red broken lines, while light blue is used for the signs of vocalization and $i h m \bar{a} l ;{ }^{35}$ the medallion appears in the background of the blank page. The title page shows a waqf certificate by Muhammad bin Ahmad called Baklmir Beg and a seal. On the top of the titlepiece, another ex-libris places this manuscript in the seventeenth-century Ottoman collection of Waysī (min kutub al-'abd Waysī) in the year 1015 H/1606$1607 \mathrm{CE}$ in Istanbul ${ }^{36}$ (Fig. 2). The headings are in chrysography outlined in black, the 'eyes' of the letters are filled in with red, while vocalization and ihmāl are in light blue. The text dividers are golden drops, sometimes clustered in groups of three. The text area is framed by a single, light blue line.

\section{Kitāb tadֵkirat ūlā al-albāb fi faḍāil ramy al-nuššāb, MS Münster UB Or. 11, fol. 1r}

[Upper and lower panel]

'Book of the reminder for the best minds about

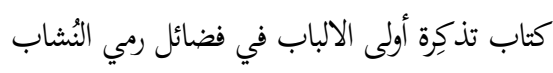
the merits of shooting with arrows'

[Medallion]

For the library of our Lord the most noble king Abū Naṣr Qāytbāy, may God strengthen the foundations of his power and prolongue the days of his reign with Muhammad as his governor.

$$
\begin{aligned}
& \text { برسم خزانة مولانا المقام الشريف المالك الاشرف } \\
& \text { ابي النصر قايتباي ثبت الله قواعد دولنه وادام ايام } \\
& \text { مملكته بمحمد واله }
\end{aligned}
$$

MS Münster UB Or. 11, fol. 45r

[Colophon]

Service rendered by the Mamlūk Yūsuf al-

Muhammadì of the al-Hawš barrack, pupil of the humble servant of God, may He be exalted, Muḥammad al-Waqāy.

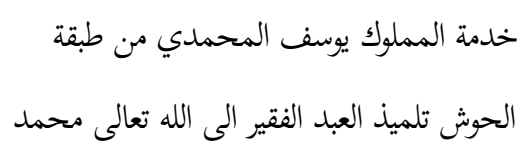

35 See Witkam 2015.

36 See Witkam 2004, 414. 


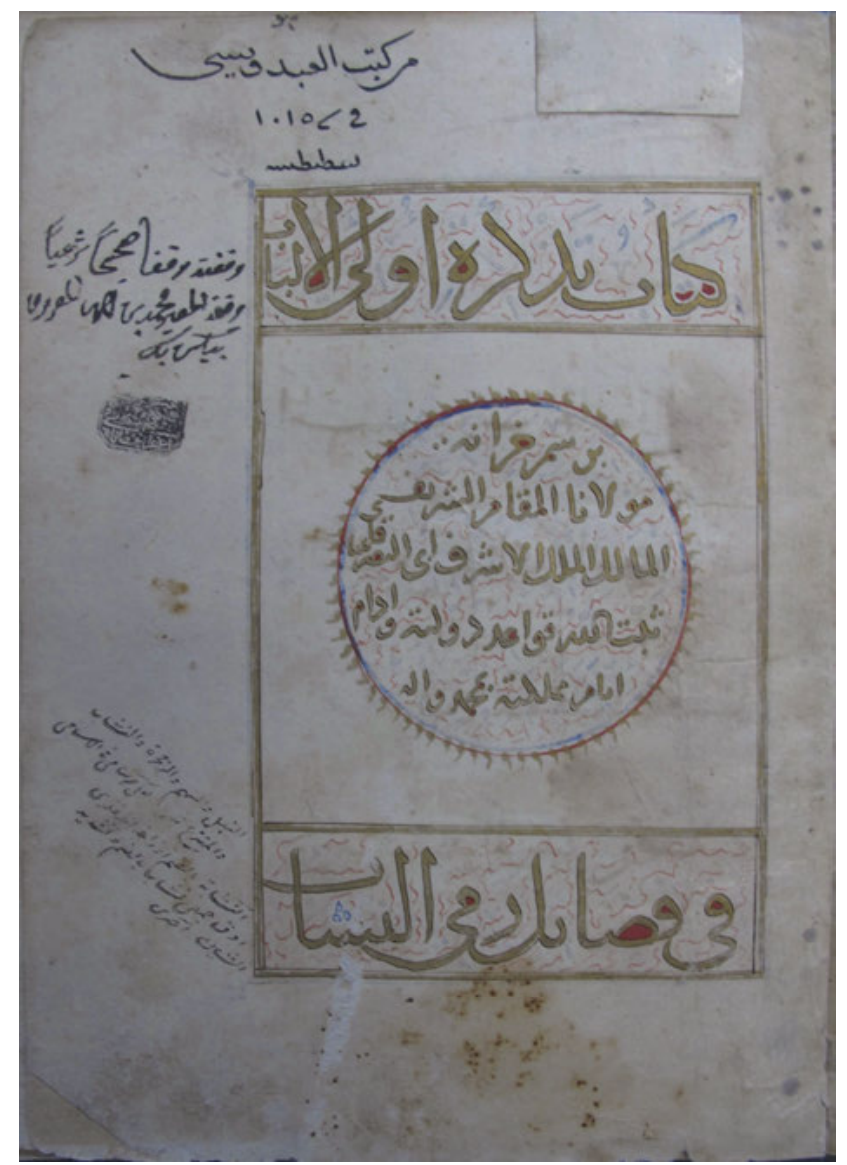

Fig. 2: MS Münster UB Or. 11, fol. 1r. Titlepiece of the Kitāb fí fậāil ramī al-nušāb ('Book about the merits of shooting with arrows').

3) The second comparandum, manuscript Istanbul Aya Sofya 2875, was copied some twenty years later for the Sultan al-Qānșūh al-Ġawrī by a Mamluk named Muhammad ibn Muhammad. The text witnessed by this manuscript is the Ps. Alexander's Kitāb al-hiyal wa-l-hurūb ('Book of the stratagems and wars'). ${ }^{37}$ This manuscript, however, has a different title: Kitāb fí 'ilm al-hurūb wa-fath al-durūb ('Book on the science of wars and the conquest of gates'). The text includes three distinct sections: (1) on fighting techniques with a number of weapons; (2)

37 See Ritter 1929, 151-152; and Raggetti (forthcoming). 
preparation of inflammable substances; (3) hydraulic and siege machines. These three textual blocks seem to have been gathered from different sources, and then transmitted together under the name of Alexander the Great. The introduction tells the story of how, in a cave near Alexandria, the Two-Horned One found a book in Greek that contained all the possible stratagems of the art of war. Its title page has the same waqf certificate and stamps as MS Istanbul Aya Sofya 3610.

The titlepiece is composed of two panels: firstly, an upper panel with the title written in white in the central element of an oval cartouche, which has a circular extension on the outer margin and a golden and blue background decoration with floral motives; and secondly, a larger, square lower panel that includes a medallion which has as its background the blank page with four stamped rosettes in each of the corners. The titlepiece is framed by a treble-line: black, red and a jagged blue one as an outer margin (Fig. 3). The chapter and paragraph headings are rubricated. The text dividers in MS Aya Sofya 2875 are simple red dots scarcely attested in the text.

Kitāb fí 'ilm al-ḥurūb wa-fatḥ al-durūb, MS Istanbul Aya Sofya 2875, fol. 1r

[Upper panel]

'Book on the science of wars and the conquest of gates'

[Lower panel / medallion]

For the library of the ruling Sultan the sovereign al-Ašraf Abū Nașr Qānșūh al-Ġawrī.

\section{MS Istanbul Aya Sofya 2875, fol. 123v}

\section{[Colophon]}

The writing of this book was finished on Thursday, the $26^{\text {th }}$ of the noble and sacred month of $\check{S} a \bar{b} \bar{a} n$ in the year $911 \mathrm{H}$./January 21, $1506 \mathrm{CE}$, the humble servant of God

Muhammad ibn Muhammad wrote it, may God forgive him, his parents, and all the Muslims. Amen, Praise be to God, Lord of the Worlds.

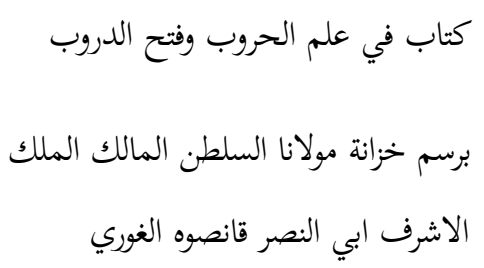

وكان الفراغ من كتابته في يوم الخميس السادس

عشرين من شهر شعبان المكرم قدره وحرمته سنة

احدى وعشر وتسع مائة وكتبه الفقير الى الله

محمد بن محمد غفر الله له ولوالديه ولجميع المسلمين امين والحمد الله رب العالمين 


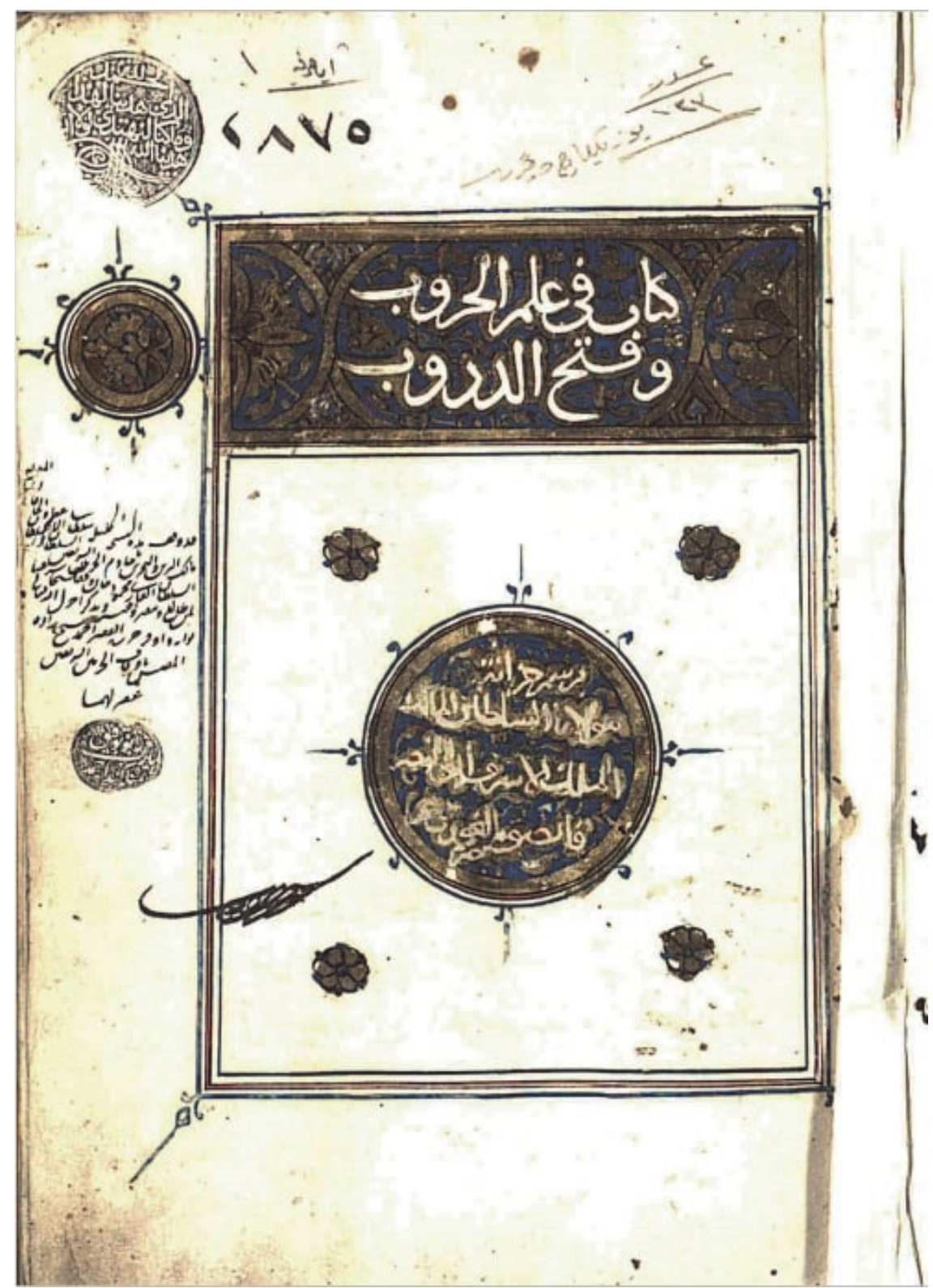

Fig. 3: MS Istanbul Aya Sofya 2875, fol. 1r. Titlepiece of the Kitāb fĩ 'ilm al-hurūb ('Book on the science of wars'). 


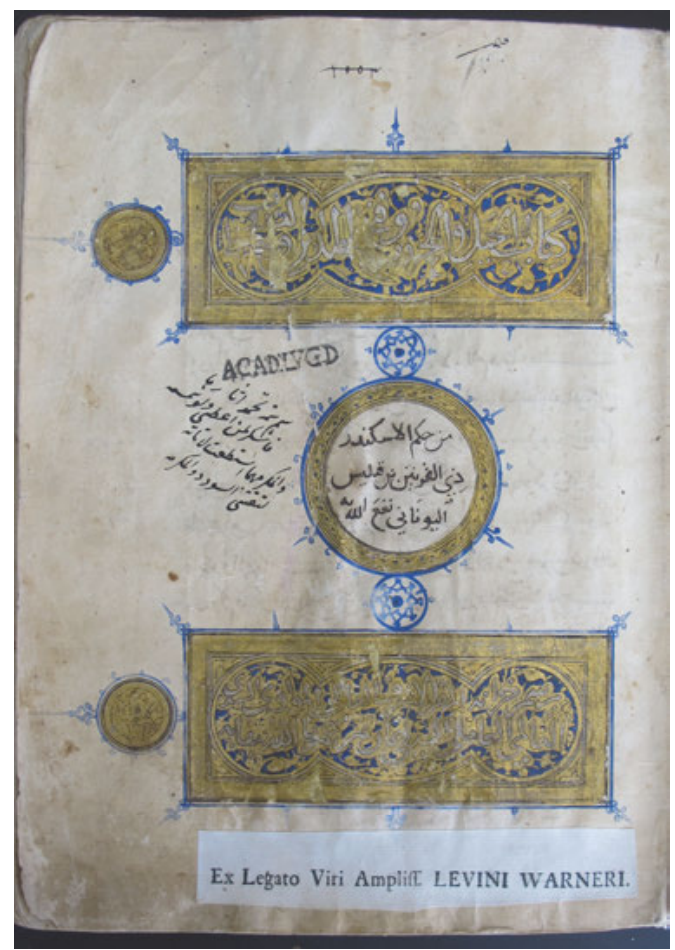

Fig. 4: MS Leiden Or. 499, fol. 1r. Titlepiece of the Kitāb fi al-hiyal wa-l-ḥurūb ('Book of stratagems and wars').

4) The third comparandum, manuscript Leiden Or. 499, transmits another copy of the same text. ${ }^{38}$ The colophon only gives the name of the copyist and his nisba, alSunbuli. ${ }^{39}$ The titlepiece is composed of three isolated elements: a circular medallion between two rectangular panels with a circular extension on the outer margin. In both the rectangular panels, the text is included in a cartouche formed by two circles on the two sides of a central ellipse. All the elements are framed by a jagged blue outer line. The writing in the panels is in white, with a golden cloudband around it, a golden vegetal motif decorating the blue background, and golden frames. The text in the medallion, stating the attribution to Alexander the

38 Helmut Ritter compared the text of this manuscript with the one transmitted by MS Aya Sofya 2875, see Witkam 2007, No. 499.

39 This nickname may refer to a Mamluk barrack, al-Sunbuliyya, or to the homonimous branch of the Khalwati sufi order, founded by Sunbul Sinan Efendi at the end of the fifteenth century. See Flemming 1977, 257. 
Great, is written in plain black and does not seem to belong to the more decorative composition of the titlepiece (Fig. 4). This manuscript contains a number of illustrations representing the hydraulic machines described in the text. ${ }^{40}$ Observing the drawings, it is clear that the same compositional elements that constitute the different titlepieces (in this, but also in the other manuscripts considered here) were used to give shape to the diagrams: stamped rosettes, concentric circles, golden frames and borders decorated with geometrical motifs. This is another clue in favour of the 'in series' decorations (Fig. 5).

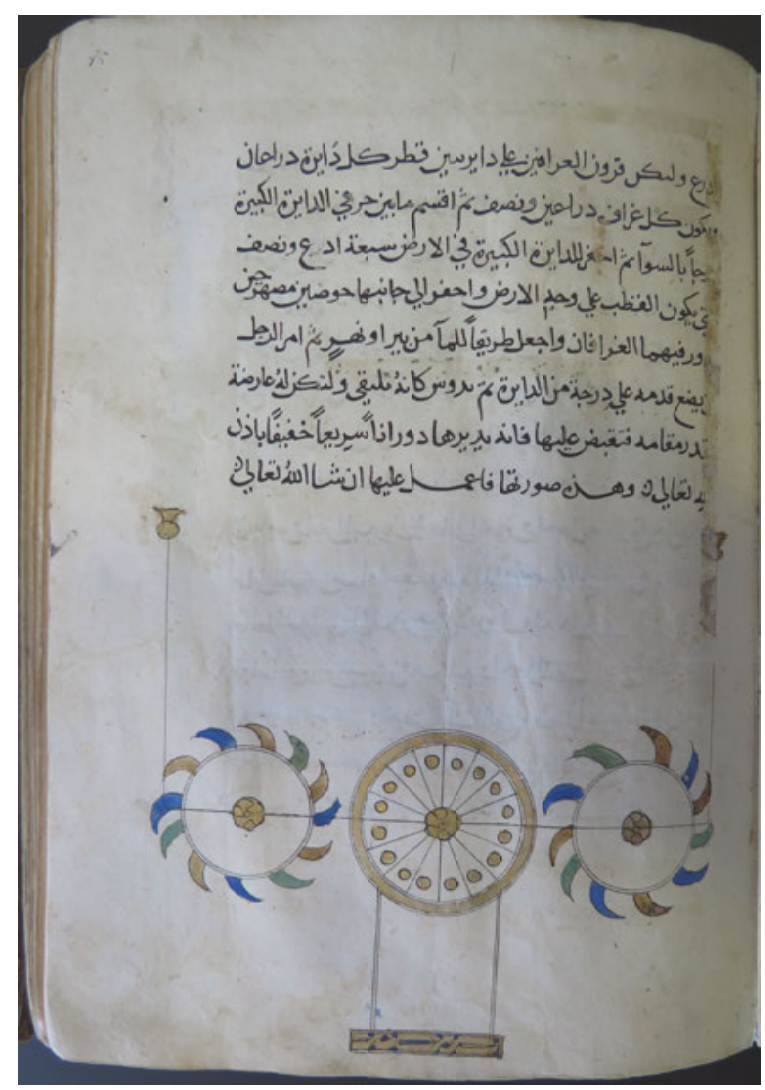

Fig. 5: MS Leiden Or. 499, fol. 85r. Illustration of a hydraulic machine in which the same compositional elements of titlepieces are used (stamped rosettes, concentric circles, frames with geometrical motives).

40 In MS Istanbul Aya Sofya 2875 space for illustrations was left, but never filled. 


\section{Kitāb fi al-ḥiyal wa-l-ḥurūb, MS Leiden Or. 499, fol. 1r}

[Upper panel]

'Book of stratagems and wars and of the conquest of cities and the defence of gates'

\section{[Medallion]}

From the wise sayings of Alexander the TwoHorned One, son of Philip the Greek, may God help him.

\section{[Lower panel]}

For the library of the most noble residence of [our patron] at Mārtamar (?), may God make it prosperous with his permanence. ${ }^{42}$

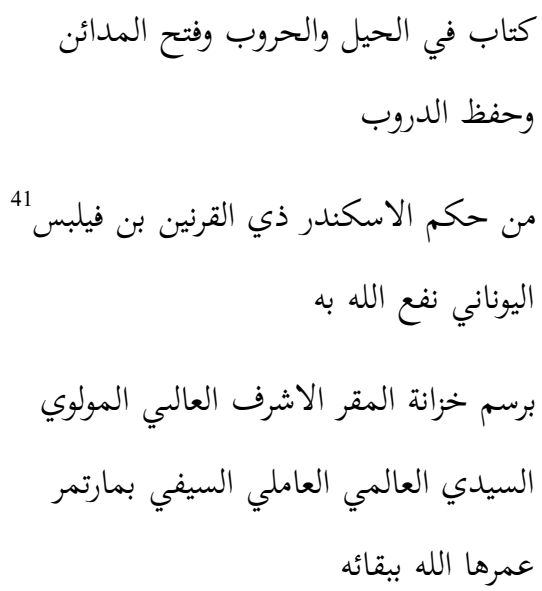

41

من حكم الاسكندر ذي القرنين بن فيلبس اليوناني نفع الله به

برسم خزانة المقر الاشرف العالي المولوي

السيدي العالمي العاملي السيفي بمارتمر

عمرها الله ببقائه - م

\section{MS Leiden Or. 499, fol. 135r}

[Colophon]

Copied by the humble servant of God, may He be exalted, Aḥmad (?) bin Yūsuf al-I'tidalī (?) known as al-Sunbulī.

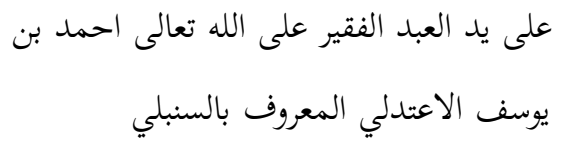

5) The fourth and last comparandum is another manuscript from the Oriental collection of the Leiden University Library, the eighth volume of a copy of the Kitāb al-filāha al-Nabațiyya ('Book of the Nabatean agriculture'). ${ }^{43}$ The titlepiece has the same structure as the one in MS Münster UB Or. 11-that is, two rectangular panels with a third squared one between them, in which the medallion is inscribed-but is more richly decorated. Title, ex-libris, and author are written in white ink outlined in gold, against a blue background with golden vegetal motifs. The texts in the upper and lower panel are included in an oblong ellipse cartouche, the extremities of which culminate in a pointed extension. The me-

41 In the manuscript, قبليس 'Qiblīs'.

42 The name of the patron is not actually given, he is indicated by a series of common epithets connected to his residence and post (al-maqarr al-ašraf al-mawlawì al-sayyidì al- 'âlimì al- 'âmilì al-sayfi); while bi-Mārtamar could be the indication of a place.

43 Witkam 2007, No. 303d; see also Vrolijk / Schmidt / Scheper 2012, 116. 
dallion-as in manuscript Istanbul Aya Sofya 3610-is scalloped with eight curved projections, filled alternately in ochre and green with vegetal motifs. The scallops, however, are separated from the medallion by a golden band. The corners of the panels are filled in ochre and decorated with golden vegetal motives too. The upper and lower panel are framed in gold, while the central one is framed in green. The whole composition of the titlepiece is framed in a double golden border, outlined by a jagged blue line, and all three panels have extensions in the outer margin of the page (Fig. 6).

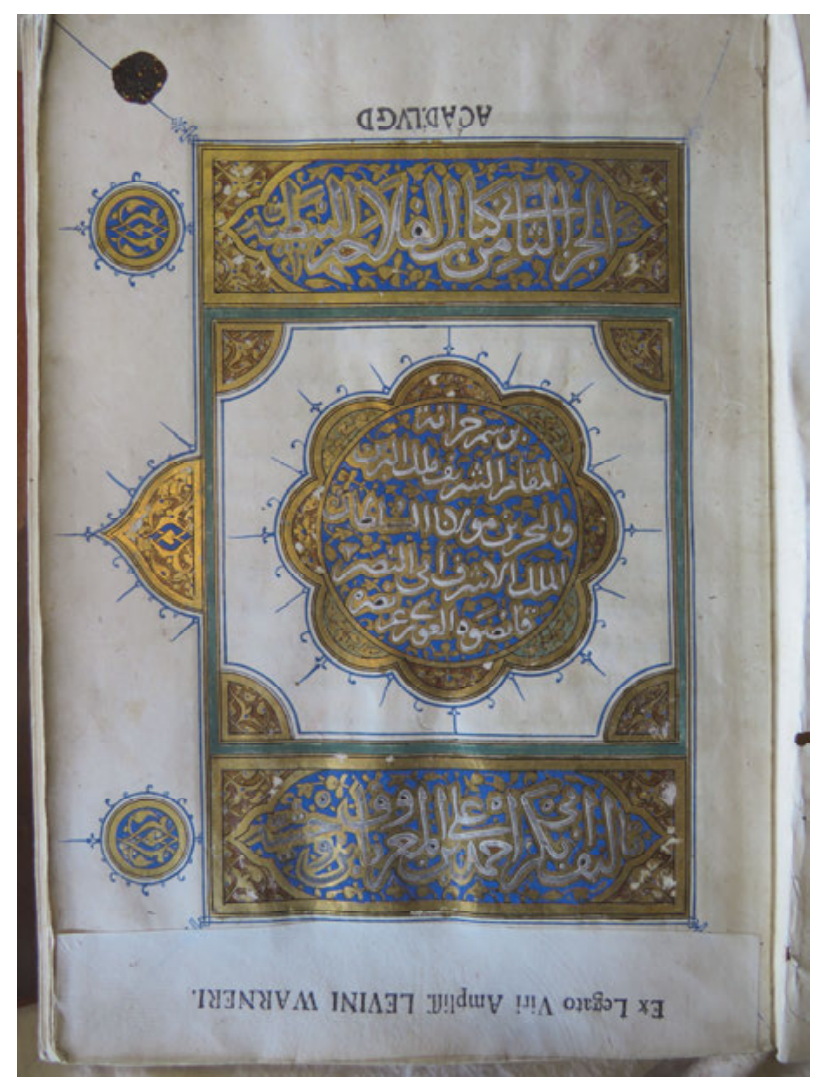

Fig. 6: MS Leiden Or. 303d, p. 1. Titlepiece of the eighth volume of the Kitāb al-filäha alNabatiyya ('Book of the Nabatean agriculture').

The manuscript is incomplete at the end, and the colophon, if ever there, is lost. Only the text of the first opening (pp. 1-2) is included in a golden frame and a blue line. The same opening has red dots and drops as text dividers, which sur- 
face sporadically in the rest of the manuscript, whose layout has not received the same attention dedicated to the initial opening. ${ }^{44}$ In many instances, in fact, it is clear that space was left for a more regular addition of these elements, which was never carried out. The chapter headings are rubricated and written in a slightly larger script.

\section{(v) Kitāb al-filāha al-Nabațiyya, MS Leiden Or. 303d, p. 1}

[Upper panel]

'Eighth part of the book of the Nabatean agriculture'

[Medallion]

For the library of the noble king of the lands and seas, our Lord the Sultan al-Ašraf Abū Naṣr Qānșūh al-Ġawrī, may his victory be glorified.

[Lower panel]

Author: Abū Bakr Aḥmad bin 'Alī known as Ibn Waḥšiyya.

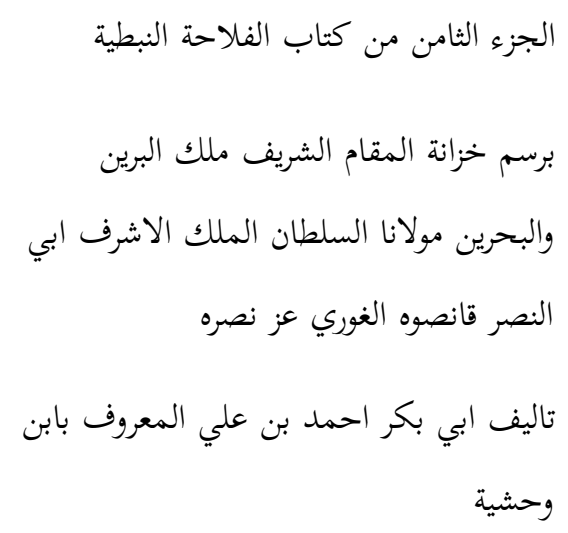

The connections between these texts based on material aspects of the manuscript witnessing to their tradition are necessary, but not sufficient to reconstruct the larger cultural phenomenon that led to their production. In her article, Barbara Flemming emphasised the role of calligraphy in these special school-exercises of the Mamluks. ${ }^{45}$ I suggest that the contents of these manuscripts deserve equal attention. Incidentally, the first objects of my research were the textual contents, and these led in turn to the discovery of material affinities.

It is rather far-fetched to talk of a Mamluk school curriculum; this does not mean, however, that the choice of contents gives the impression of having been haphazardly made. The more examples collected, the clearer the choice of contents mirroring the interests of the Mamluk readership and barrack literates will

44 See MS Leiden Or. 303d, pp. 22, 43, 60, 62, 69, 83, and 90.

45 See Flemming 1977, 258-259: 'most of these manuscripts belonged to a larger number of texts which might be called special school-exercises of the Mamluks, in which emphasis was laid on standards of calligraphy'. 
become. The present examples confirm that furūsiyya literature was certainly among the interests of the Mamluks, and the manuscripts Münster UB Or. 11, Istanbul Aya Sofya 2875 and Leiden Or. 499 all fall into this genre. The Kitāb alhiyāl attributed to Alexander the Great may be the key to the understanding the inclusion of the pseudo-Aristotelian Kitāb al-aḥğăr among the titles relevant for Mamluk school training. The contents of Ps. Alexander's second section on inflammable substances focus on technical materials that often take the form of recipes, in which mineral ingredients play a major role. Looking at the Ps. Aristotle through Alexander's lens, the former-in addition to al-Bïrūnī's work on the subject-appears to be a répertoire of the primary ingredients for this technical branch of furūsiyya. Copying these texts at the twilight of the Mamluk sultanate might even have been a conservative statement in the contemporary debate on the status and use of gunpowder and firearms. ${ }^{46}$ The pharmacological component of the Ps. Aristotle reminds us of the interest in medicine, witnessed also by other titles. The Kitāb al-filāha al-Nabațiyya of manuscript Leiden Or. 303d opens a larger perspective on the inclusion of natural sciences along with their applications-with components of curiosa as well-among Mamluk interests.

\section{Concluding remarks}

The MS Istanbul Aya Sofya 3610 represents a summa of the technical materials on stones, minerals, and their uses, which entered the Arabo-Islamic tradition in the ninth-tenth century. Almost all the streams of tradition that were received and reelaborated in the early Abbasid cultural milieu are represented here: Greek (ancient, Hellenistic, and late antique), Pahlawi, Indian, and (pre-Islamic?) Arabic. Also, the original compositions in Arabic were heavily influenced in that period by the multilingual atmosphere of the time of translations.

In the Mamluk context, the reception of the Ps. Aristotle was probably triggered by some elements of the furūsiyya literature, namely the preparation of inflammable substances. The Ps. Aristotle, in turn, attracted and introduced a number of shorter texts-both for content affinity and codicological reasons-that used to circulate together as set of technical indications about stones, minerals, and their manipulation (for alchemy, medicine, talisman making).

A close comparison with the composite MTM Paris BnF Ar. 2775 reveals that these shorter technical texts used to circulate together. The MTMs on stones and

46 See David Ayalon 1956, 24-26. 
minerals considered here seems to confirm the idea that the principal and more extended work exercised a sort of 'textual magnetism' on shorter compositions dealing with related aspects. These collateral texts tend to cluster in recurrent combinations. If the rolling stones of the title are taken here as a metaphor for the different textual blocks circulating in the fluid tradition of texts on stones and minerals, it is indeed possible to track the patterns of their clustering.

By cross-referencing the data that derive from the study of this MTM as an object with those from the analysis of its textual contents, it is possible to reconstruct some more general cultural and literary trends, and perhaps even a small bit of the Mamluk curriculum, in particular some of its technical contents. Moreover, a content-oriented approach can offer a more articulated perspective on the great number of manuscripts that share these material features-in particular, the titlepiece-and the ways in which they were produced and collected.

\section{References}

Andrist, Patrick / Canart, Paul / Maniaci, Marilena (2013), La syntaxe du codex. Essai de codicologie structurale (Bibliologia: Elementa ad Librorum Studia Pertinentia, 34), Turnhout: Brepols. Ayalon, David (1949), 'The Circassians in the Mamluk Kingdom', in Journal of the American Oriental Society, 69/3: 135-147.

Ayalon, David (1956), Gunpowder and Firearms in the Mamluk Kingdom. A Challenge to a Mediaeval Society. London: Valentine Mitchell.

Ayalon, David (1968), 'The Muslim City and the Mamluk Military Aristocracy', in Proceedings of the Israel Academy of Sciences and Humanities 2, Jerusalem: Israel Academy of Sciences and Humanities, 311-329.

Behrens-Abouseif, Doris (2019), The Book in Mamluk Egypt and Syria (1250-1517). Leiden, Boston: Brill.

van Bladel, Kevin (2009), Arabic Hermes. From Pagan Sage to Prophet of Science. Oxford, New York: Oxford University Press.

Deutscher, Guy (2011), Through the Language Glass. Why the World Looks Differently in Other Languages. London: Arrow Books.

Flemming, Barbara (1977), 'Literary Activities in Mamluk Halls and Barracks', in Myriam RosenAyalon (ed.), Studies in Memory of Gaston Wiet. Jerusalem: The Hebrew University, Institute of Asian and African Studies, 249-260.

Gacek, Adam (2009), Arabic Manuscripts. A Vademecum for Readers. Leiden, Boston: Brill.

Hammer-Purgstall, Joseph (1849), Abhandlung über die Siegel der Araber, Persen und Türken. Vienna: C. Gerold \& Sohn.

Käs, Fabian (2010), Die Mineralien in der arabischen Pharmakognosie. Eine Konkordanz zur mineralischen Materia medica der klassischen arabischen Heilmittelkunde nebst überlieferungsgeschichtlichen Studien, 2 vols. Wiesbaden: Harrassowitz.

Käs, Fabian (2015), Al-Maqrīzīs Traktat über die Mineralien: Kitāb al-Maqāṣid al-saniyyah limárifat al-ağsām al-mádiniyyah. Leiden, Boston: Brill. 
Kazimirski, Alexandre de Biberstein (1860), Dictionnaire arabe-français, 2 vols. Paris: Maisonneuve. Lane, Edward William (1863-1893), Arabic-English Lexicon, 8 vols. London: Willams \& Norgate. de Menasce, Paul (1942-1945), 'Un lapidaire pehlewi', in Anthropos, 37/40: 180-185.

Pingree, David (1989), 'Indian Planetary Images and the Tradition of Astral Magic', in Journal of the Warburg and Courtauld Institute, 52:1-13.

Raggetti, Lucia (2014), 'The "Science of Properties” and its Transmission', in Justin Cale Johnson (ed.), In the Wake of the Compendia. Infrastructural Contexts and the Licensing of Empiricism in Ancient and Medieval Mesopotamia (Science, Technology, and Medicine in Ancient Cultures 3). Berlin: De Gruyter, 159-176.

Raggetti, Lucia (forthcoming), 'The Treasure of Alexander. Stories of Discovery and Authorship', in Stefanie Brinkmann, Giovanni Ciotti, Martin Delhey and Stefano Valente (eds), Education Materialized: Reconstructing Teaching and Learning Contexts through Manuscripts (accepted for publication).

Ritter, Helmut (1929), 'La parure des cavaliers und die Literatur über die ritterlichen Kunst', in Der Islam, 18: 116-154.

Ruska, Julius (1912), Das Steinbuch des Aristoteles mit literargeschichtlichen Untersuchungen nach der arabischen Handschrift der Bibliothèque Nationale. Heidelberg: Winter.

Ruska, Julius (1919), Griechische Planetendarstellungen in arabischen Steinbüchern. Heidelberg: Winter.

Ruska, Julius (1926), Tabula Smaragdina. Ein Beitrag zur Geschichte der hermetischen Literatur. Heidelberg: Winter.

Ullmann, Manfred (1971), 'Yūḥannbn Sarābiyūn: Untersuchungen zur Überlieferung seiner Werke', in Medizinhistorisches Journal, 6: 278-296.

Ullmann, Manfred (1972a), Die Natur- und Geheimwissenschaften im Islam. Leiden: Brill.

Ullmann, Manfred (1972b), 'Das Steinbuch des Xenocrates von Ephesos', in Medizinhistorisches Journal, 7: 49-64.

Ullmann, Manfred (1973), 'Neues zum Steinbuch des Xenocrates', in Medizinhistorisches Journal, 8: 59-76.

Vrolijk, Arnoud / Schmidt, Jan / Scheper, Karin (2012), Turcksche boucken. De oosterse verzameling van Levinus Warner, Nederlands diplomat in zeventiende-eeuws Istanbul / The Oriental collection of Levinus Warner, Dutch diplomat in seventeenth-century Istanbul. Eindhoven: Lecturis.

Witkam, Jan Just (1978), Seven Specimens of Arabic Manuscripts Preserved in the Library of the University of Leiden, Leiden.

〈http://islamicmanuscripts.info/inventories/leiden/or01000.pdf>

Witkam, Jan Just (2004), review of G. Schoeler (ed.), Die Handschriften der Universitätsbibliothek Basel (2001), in: Bibliotheca Orientalis 3-4: 412-415.

Witkam, Jan Just (2007), Inventory of the Oriental Manuscripts of the Library of the University of Leiden, Vol. 1. Leiden: Ter Lugt Press.

〈http://www.islamicmanuscripts.info/inventories/leiden/or01000.pdf>

Witkam, Jan Just (2015) ‘The Neglect Neglected. To Point or Not to Point, That is the Question', in Journal of Islamic Manuscripts, 6: 376-408. 
